\title{
MEMÓRIAS DA BAHIA: CARTAS DA IMIGRAÇÃO GALEGA
}

\section{MEMORIES OF BAHIA: LETTERS OF THE GALICIAN INMIGRATION}

\author{
Lúcia Tavares Leiro ${ }^{1}$ \\ Universidade do Estado da Bahia
}

\begin{abstract}
Resumo: As cartas dos irmãos Leiro Duran formam um acervo importante para a memória da imigração galega em Salvador. Como gênero discursivo (BAKHTIN, 2016), as cartas são textos socialmente e historicamente produzidos na cultura. Por meio delas, os imigrantes galegos falavam com os seus familiares na Galícia e enviavam remessas financeiras e culturais. Estudálas nos permite adentrar nos meandros dos enunciados, no repertório léxico-discursivo do escrevente, a partir de sua voz, impressões, motivações e sentimentos. As três cartas usadas neste artigo foram escritas por Candido Leiro Duran ao seu pai, durante a primeira metade do século XX. A investigação baseou-se na leitura e digitalização dos manuscritos, transcrição digitada e análise fundamentada no conceito de egodocumento (GROßE, 2015), de modalidade discursiva (BARCIA, 2012), de egosespecularidade e ancestralidade discursiva (LEIRO, 2021).
\end{abstract}

Palavras-chave: Egodocumento; Imigração; Modalidade discursiva; Ancestralidade discursiva; Galícia.

1 lleiro@uneb.br 
Abstract: The letters of the Leiro Duran brothers form an important collection for the memory of the Galician immigration in Salvador. As a discursive genre (BAKHTIN, 2016), letters are texts socially and historically produced in culture. Through them, Galician immigrants spoke to their families in Galicia and sent financial and cultural remittances. Studying them allows us to enter the intricacies of utterances, into the scribe's lexical-discursive repertoire, from his voice, impressions, motivations and feelings. The three letters used in this article were written by Cándido Leiro Duran to his father during the first half of the 20th century. The investigation was based on the reading and digitization of manuscripts, typed transcription and analysis based on the concept of egodocument (GROßE, 2015), discursive mode (BARCIA, 2012), egospecularity and discursive ancestry (LEIRO, 2021).

Keywords: Egodocument; Inmigration; Discursive mode; Discoursive ancestrality; Galicia.

\section{INTRODUÇÃO}

Cada escrita é uma inscrição do sujeito na materialidade da história e é por meio da linguagem que as ideias, os valores, os princípios organizadores da vida social são postos em trânsito nas práticas sociais. As cartas são um gênero do discurso (BAKHTIN, 2016, p. 262) porque apresentam, como sugeriu o filósofo russo, um eixo enunciativo "particular e individual", e outro "relativamente" estável. Por séculos, exerceram um papel sociointerativo importante entre os sujeitos, influenciando os comportamentos, modificando a história, significando mundos. Ajudaram a construir reinos, civilizações e, no plano mais privado, educavam sentimentos e reações frente aos ritos e rituais cotidianos. Por esta razão, as cartas são um material rico para os estudos discursivos, porque expõem os mecanismos linguísticos e performáticos do sujeito, em um dado momento histórico e em condições sociais específicas, observando e analisando os efeitos de sentido provenientes das escolhas enunciativas do escrevente, que faz reverberar a voz tão desprestigiada da primeira pessoa em função da terceira supostamente neutra.

Por se tratar de fonte primária e, no caso específico da minha investigação, manuscrita por membros de uma mesma família, os irmãos Leiro Duran, as cartas proporcionam um estudo instigante e ao mesmo tempo indispensável para a construção da narrativa deste grupo familiar e, por 
extensão metonímica, da história da Galícia e de Salvador. Este material faz parte do acervo familiar, que se converte, neste momento, em corpus de análise para os estudos discursivos da imigração, ainda que o tema da migração galega já tenha sido investigado por outros pesquisadores brasileiros e galegos, historiadores e cientistas sociais (BACELAR, 1994; VÁZQUEZ, 2017; BRAGA, 1995), para citar alguns.

A partir das cartas podemos identificar as motivações do escrevente, as suas expectativas, escolhas, que, embora sejam respostas individuais, são afetadas pela história. É nesta confluência e tensão do eu com o outro que entendo os egodocumentos, como espaço discursivo do constructo do eu na relação com o mundo. Jaques Presser, segundo García (2009), foi o primeiro a fazer uso da palavra egodocumento:

Em meados da década de 1950, o historiador Jacob Presser cunhou a palavra egodocumento, termo que passou a significar autobiografias, memórias, diários, cartas pessoais e outros textos em que o autor escreve, explicitamente sobre si mesmo, seus próprios assuntos e sentimentos". (Dekker, Rudolf, 2002: 13). Mas os textos autobiográficos também são conhecidos como literatura do self, literatura do ego, literatura do ego, literatura documental em primeira pessoa. Tudo o que foi dito anteriormente com respeito a essa literatura de si não exclui a existência de autobiografias escritas na segunda pessoa ou outras modalidades e exceções². (GARCÍA, 2009, p. 7)

Portanto, o estudo dos egodocumentos está centrado no texto, particularmente na pessoa do eu escrevente, porém, devemos ter em conta que

\footnotetext{
2 "A mediados de los años cincuenta del siglo XX el historiador Jacob Presser acuñó la voz egodocumento, término que venía a significar las autobiografías, memorias, diarios, cartas personales y otros textos en los cuales el autor escribe, explícitamente acerca de sí mismo, de sus propios asuntos y sus sentimientos." (Dekker, Rudolf, 2002:13). Pero los textos autobiográficos también se conocen como literatura del yo, literatura del mí, literatura del ego, literatura documental en primera persona. Todo lo referido anteriormente con respecto a esa literatura del yo, no excluye la existencia de autobiografías escritas en segunda persona $u$ otras modalidades y excepciones." (GARCÍA, 2009, p. 7)
} 
toda significação perpassa pelo ato de leitura, portanto de outra inscrição do ego, tornando mais complexo os sentidos tecidos no gesto discursivointerpretativo. Este encontro egoespecular discursivo $0^{3}$ produz um encontro de descobertas, quando o repertório memorialístico é compartilhado pelo eu escrevente e o eu leitor.

Os egos quando se tocam no ato da leitura, e me refiro aqui particularmente à experiência de sujeitos pertencentes à cultura galega ou ligados a ela de alguma forma, faz com que a memória seja ativada, significada, considerando que estamos lidando com acervos, com correspondências que extrapolam os primeiros interlocutores, para se dirigirem à memória do leitor de outro tempo. É desta perspectiva que entendo também as cartas como objeto sagrado por parte dos guardiães da memória. Adentrar à memória ancestral e, por conseguinte, à memória de cada imigrante galego, é um ato que requer cuidados, a fim de preservar os afetos e o respeito mútuo. Este aspecto me remete a outro conceito-base neste estudo, o de ancestralidade discursiva, que utilizo para identificar e explicar as referências ancestrais - valores, visão de mundo, ritos e rituais - presentes no texto, nas escolhas lexicais ao se referir ao acervo simbólico galego. Portanto, o conceito de ancestralidade discursiva é usado aqui como dispositivo de análise por meio do qual os imigrantes e os seus descendentes se fundamentam e se constituem, ao imergirem com as narrativas orais ou escritas e com outras formas de expressão narratológica ou representacional. É oportuno destacar que considero ancestralidade discursiva um conceito útil para a interpretação de textos, porque opera com elementos extrínsecos e intrínsecos a eles. É por meio do texto que os sujeitos materializam

\footnotetext{
${ }^{3}$ Por egoespecularidade entendo a conectividade entre o eu escrevente e o eu da crítica. A metáfora do espelho está associada ao autoconhecimento, à consciência do sujeito de sua história, ao se ver diante de si mesmo nas narrativas de seus ancestrais. Deste modo, a egoespecularidade estaria associada a outro conceito, o de ancestralidade discursiva, isto é, aos discursos que mostram um vínculo material e imaterial entre membros de um mesmo grupo familiar, passado de uma geração para outra.
} 
os discursos, organizam e criam realidades, inclusive e, sobremaneira, a si próprios. O discurso cria realidades e constrói a imagem de si e do mundo:

O discurso é muito mais do que a mera soma de um número indeterminado de unidades linguísticas dotadas de coerência e coesão. Sob esta etiqueta serão fornecidos os usos linguísticos, orais ou escritos, que são desenvolvidos em um contexto específico. (BARCÍA, 2012, p. 137)

O contexto das cartas dos Irmãos Leiro Duran ${ }^{5}$ é o da imigração, o momento de adaptação ao país de acolhida. Elas mostram como os imigrantes recriaram as suas vidas no país receptor, tendo os valores galegos preservados pelos ritos e rituais familiares: gastronomia, festa, empreendedorismo, mas sem deixar de interagir com a cultura afro-baiana também presente na cidade. A ancestralidade discursiva, ao ser entendida como dispositivo de análise, repito passa a ser necessária para o investigador das narrativas imigratórias, sobretudo aos que possuem laços familiares com a Galícia. Como explicar o interesse, as motivações de um descendente de galego pelos estudos imigratórios de sua gente, senão pela memória comum? Que sentidos podem ser suscitados neste encontro egoespecular?

As cartas dos irmãos Leiro Duran estavam sob posse de familiares há quase um século, e somente em 2018 tive acesso a elas, no momento em que visitava parentes na Galícia. As famílias tinham por hábito guardar cartas como forma de preservação da memória; uma preocupação em formar o elo

\footnotetext{
4 "El discurso es mucho más que la mera suma de un número indeterminado de unidades lingüísticas dotadas de coherencia y cohesión. Bajo esta etiqueta se dispondrán los usos lingüísticos, bien orales o escritos, que se desarrollen en un contexto determinado." (BARCÍA, 2012, p. 137)

${ }^{5}$ A família Leiro, uma das famílias mais antigas de Moscoso, viveram, como tantas outras, a experiência da emigração. As cartas foram escritas particularmente pelos filhos já emigrados ao seu pai, ainda que no vocativo apareçam os nomes do pai e da mãe. As cartas foram escritas, majoritariamente, pelos irmãos: Cándido, Manuel, Claudio (Claudino) e Francisco, destinadas aos seus pais, Albino Leiro e Balbina Casqueiro.
} 
necessário de transmissão patrimonial simbólica aos descendentes, tais como os saberes, a cultura, os ritos, afetos, quiçá o desejo de não ser esquecido. Guardar uma carta significa prolongar a vida dos que morreram, presentificando-os na memória dos que vivem, a fim de que a posteridade não se esqueça de que o início de uma história é bem mais distante e, paradoxalmente, próximo do que qualquer existência. É tentar assegurar que tudo o que foi realizado, todo esforço, não se perca no meio de tantos outros discursos que esvaziam os sujeitos de pertencimento, desconectando-os de suas raízes culturais e, consequentemente, fazendo-os desconhecedores de sua história. As cartas de familiares representam mais do que um meio de comunicação, elas foram, desde sempre, um instrumento necessário, inclusive pedagógico, para reeducar os sentimentos, constituir redes de pertencimento e de preservação dos costumes e até mesmo de mediação de conflitos gerados pela inobservância dos ritos. Os rituais chegam a nós agora pela palavra.

Dos recursos léxico-discursivos usados pelo escrevente para construir a imagem de si, destaco as figuras de linguagem, sobretudo a hipérbole. Esta figura aparece com alguma frequência nas cartas. É um recurso da linguagem que possui forte carga emocional, contudo ela deve ser entendida discursivamente, no contexto do enunciado, no nosso caso, de grande sofrimento e dificuldades por causa da imigração, portanto a palavra serve como alívio e, portanto, libertação de tais sentimentos. Deste modo, a hipérbole não deve ser tratada apenas como um exagero, já que esta exacerbação pode revelar uma opressão sobre os sujeitos que, por sua vez, encontra na palavra catártica uma maneira de extravasar e atenuar a sua dor:

Padre tanben me diçe que nosostros todos estamos enfermos pois conla ayuda de dios lutaremos asta laultima hora (destaque meu) 
Ao todo foram 80 cartas, porém apenas 44 fizeram parte da minha investigação, já que estas possuíam os elementos estruturais completos e constitutivos deste gênero discursivo, como os identificadores de tempo, lugar e de autoria, além de estarem legíveis em sua grande parte. Este contato com os manuscritos me permitiu realizar um percurso memorialístico-pessoal e acadêmico-que me deu as motivações necessárias para que o objeto e o recorte teórico pudessem se constituir enquanto sentido, textualidade, enlaçando o pessoal ao científico. Este movimento egoespecular me oportunizou fazer novas leituras, visitações, tanto do ponto de vista macro, como as idas a instituições de pesquisa, bibliotecas, centros culturais, quanto do ponto de vista micro, ao me encontrar com familiares, sua cotidianidade, história e rituais galegos ${ }^{6}$. As leituras que precedem este trabalho ajudaram a compor o meu acervo sobre a imigração e me puseram em contato com narrativas e pesquisas de autores que escreveram sobre o tema, já citados anteriormente, o que foi fundamental para a minha compreensão e para a análise das cartas.

As cartas do meu avô e dos meus tios-avôs ${ }^{7}$ me permitiram entender mais a imigração deste grupo, bem como seus objetivos, e, ainda, me possibilitaram conhecer os temperamentos, as necessidades, alegrias e tristezas. dos escreventes a partir da experiência imigratória. Um dos estudos mais completos sobre a emigração galega é o de Alfonso Magariños, A Emigración, 1999, livro que apresenta uma visão ampla e criteriosa da prática migratória galega, mostrando diferentes visões sobre as razões da emigração, tanto para os outros continentes, quanto para o continente europeu, salientando, ainda, o movimento que ocorria entre províncias da própria Galícia. No caso dos irmãos Leiro Duran, estes emigraram para o continente americano, em busca de

\footnotetext{
${ }^{6}$ Morei na Galícia por quase dois anos e meio, foi a maneira de perceber a Galícia do lugar de neta de imigrantes galegos e de me fazer imergir no tema da imigração, sendo impossível separar o percurso pessoal do recorte teórico-metodológico deste estudo.

7 No total, Cándido escreveu 19 cartas; Francisco 13; Manuel 10; Claudino (Claudio) 02. Edith (Judith), esposa de Cándido, escreveu 03.
} 
melhores condições de vida, e se instalaram na primeira capital brasileira, situada na região Nordeste do Brasil, com o objetivo de trabalharem e enviarem remessas de dinheiro para os seus familiares na Galícia, mantendo, desta maneira, a sua família de origem, além daquela que formavam no país de acolhida. Os imigrantes galegos saíam da casa matriz com pretensões de um dia regressarem com estabilidade financeira.

De forma resumida, posso dizer que as cartas dos imigrantes tinham como objetivo principal informar sobre as remessas de dinheiro (pesetas) à sua família na Galícia, mas também enviar mercadorias e objetos, a exemplo de tabaco, tecidos, fotografias. Visavam também compartilhar as preocupações e os rituais dos dois lugares: mortes, casamentos, trabalho, enfermidades, festas religiosas - a dos Remédios e o Natal-colheita, negócios, ou seja, remessas culturais ${ }^{8}$. Junto à remessa de dinheiro, enviavam também as remessas afetivas, mostrando a vida dos imigrantes no novo país, os sentimentos, expectativas, superações, enfim os efeitos da imigração sobre os que partiram e os que ficaram. É importante destacar neste momento que, embora os galegos emigrassem para outros lugares antes do século $X X$, foi neste momento que a imigração se avolumou, tornando-se uma das bases econômicas da Galícia e de outros países da Europa, a ponto de movimentar navios de diferentes nacionalidades e uma logística que não começava nos barcos, mas antes, com a captação de pessoas por parte de agentes em lugares de maior concentração (MAGARIÑOS, 1999, p. 30-32), como as feiras. Logicamente que a situação de extrema dificuldade e instabilidade gerada pelas guerras mundiais e as próprias condições históricas e políticas em que viveu a Galícia retrasou o seu

\footnotetext{
8 Apesar de Juan Flores (FLORES, 2009, p. 4) definir remessas culturais como as remessas simbólicas dos remigrados à casa de origem, amplio este conceito para qualquer envio imaterial, simbólico, trocada pelos imigrantes e a casa matriz, me baseando unicamente nos aspectos linguístico-semânticos das palavras remessa e cultural. É importante destacar que a remessa no contexto galego era uma via de mão dupla, atendia tanto os familiares da Galícia quanto do Brasil.
} 
desenvolvimento, e a promessa de vida melhor em outro país acabava seduzindo os galegos a saírem de sua terra e, como em alguns casos, não regressarem.

\section{ANÁLISE DE TRÊS CARTAS}

Selecionei para este artigo as três primeiras cartas (digitadas por mim) de Cándido Leiro Duran': a primeira, escrita em 27 de julho de 1924, a segunda em 02 de novembro de 1927 e a terceira em de 27 de novembro de 1928. Note-se, nesta pequena amostra, que há uma lacuna entre as cartas: três anos e um ano, respectivamente. Isso não significa que houve de fato este hiato, até porque é possível que algumas cartas tenham se perdido durante estes quase cem anos. De qualquer sorte, os imigrantes não escreviam com muita frequência, uma vez que o meio de comunicação era muito precário e havia uma incerteza quanto à chegada das correspondências às mãos dos destinatários pelos correios, fazendo com que os imigrantes preferissem encarregar as correspondências a alguém de confiança que fosse para a Galícia. O dinheiro era entregue en persona, havendo, portanto, uma relação de confiança, fortalecida pela rede social entre os imigrantes, em razão da própria imigração, ou por relações já consolidadas antes da viagem, por relações de parentesco ou vizinhança.

\section{A PRIMEIRA CARTA ${ }^{10}$}

A primeira carta tinha três objetivos, nesta ordem de apresentação: explicar a razão de o escrevente ter omitido de seu pai acidentes ocorridos com

\footnotetext{
${ }^{9}$ Segundo filho de Balbina e Albino, casou-se com Judith em 24 de novembro de 1928. Teve com Judith 10 filhos: Isabel, Cândido, Albino, Eduardo, Rosa (Rosita), Wilson, Carlos, Alfonso, Henrique, Marcial.

${ }^{10} \mathrm{O}$ acervo que tenho em mãos me informa que a primeira carta foi enviada em 1924 e a última em 1948.
} 
familiares; demonstrar a sua discordância sobre a proposta de casamento feita a uma parente e, por fim, sobre a colheita do milho.

Do ponto de vista estrutural, a carta apresenta um arcabouço tripartite bem definido: a introdução, formada pelo vocativo e saudações, predominantemente injuntiva; em seguida a exposição dos assuntos, na qual predomina a narração, e, por fim, o desfecho, formado por expressões de cortesia, e fórmulas de despedida, restabelecendo o ânimo e a promessa de um reencontro, recuperando, assim, o efeito injuntivo do texto. É importante enfatizar que as cartas tinham como objetivo principal o envio de dinheiro, porém nem todas, levando-nos a entender que as correspondências tinham o objetivo também de estabelecer remessas culturais ${ }^{11}$. A carta em questão nos dá um exemplo disso, ao tratar da colheita do milho e do pedido de casamento, ressaltando a importância dos rituais da terra e os ritos sociais para a manutenção do vínculo familiar. $\mathrm{O}$ matrimônio era a maneira pela qual os galegos ampliavam a sua influência na comunidade e se projetavam diante dos membros da família e do povoado.

Retomando os aspectos textuais da carta, cito um fragmento digitado da carta manuscrita que corresponde à introdução:
Amante padre dios quiera que al hrreceber estas dos letras mal es- critas que-se encuentre de una perfeita saú $^{3}$ na comp. de toda familia pues amia y de mís Ermanos y tios y tia y primos es mui hrregular adeus gracias. ${ }^{12}$

\footnotetext{
${ }^{11}$ Remesssas culturais são envios simbólicos, imateriais, que formam a riqueza cultural de um determinado grupo social. As remessas culturais estão alinhadas ao conceito de ancestralidade, na medida em que a troca simbólica dos ritos e dos valores por meio dos textos contribui para o sentimento de pertença entre os membros

${ }_{12} \mathrm{Na}$ transcrição, foram mantidas não apenas a ortografia, mas, também, a estrutura da carta. Optei por uma transcrição diplomática do texto, baseada em edição fac-similar.
} 
A linguagem usada pelo sujeito escrevente para se comunicar com o pai é constituída de diferentes níveis que demonstram formalidade, ao evocar respeito e cuidado-em razão da hierarquia entre eles-e informalidade, quando insere, por exemplo, marcadores conversacionais característicos dos textos orais: o uso do vocativo para chamar a atenção do interlocutor, frases curtas em ordem direta, fragmentada, entre outros aspectos. Portanto, há uma mistura de registros, dos menos espontâneos, principalmente no início e final da carta, aos mais naturais, presentes no desenvolvimento da correspondência. Estes aspectos mostram como a estrutura e a linguagem confluem e contribuem para a escritura, em relação à forma a ser dirigida ao seu interlocutor: ora polida, respeitosa, ora confidencial, íntima.

Nesta carta, o sujeito escrevente alude a uma preocupação do pai com a saúde dos imigrantes: "Padre tanben me diçe que nosotros todos estamos enfermos pois conla ayuda de dios lutaremos asta laultima hora." Ao retomar, através do discurso indireto, a fala do pai, "me disse que", o escrevente sugere que o seu interlocutor havia feito um comentário em carta anterior, levando-o a ser firme na resposta, por meio de uma metáfora combativa ancestral, luta13, e de uma hipérbole "asta laultima hora". Em um mesmo enunciado, duas combinações léxicas com efeito discursivo de bravura e resistência. Deste modo, o eu escrevente enuncia um discurso esperançoso, considerando que seus familiares dependiam do sucesso da emigração para melhorar as condições de vida. Demonstrar, portanto, resistência e coragem era uma maneira de confortar a família na Galícia, e de modelar uma autorrepresentação.

A doença, nos anos 20, para os galegos e espanhóis, de um modo geral, era um espectro que os rondava, fosse pelo clima de guerra vivido na Europa,

\footnotetext{
${ }^{13}$ Uma palavra ancestral é aquela que faz parte do acervo, do repertório linguístico de um grupo social, por razões históricas ou por testemunho. Ela faz parte da memória do sujeito que a recebe de seus antepassados ou a vivência. No caso desta família em estudo, a memória é ao mesmo tempo herdada e vivida.
} 
fosse pelas pandemias que assolavam o mundo. Deste modo, a doença pode ser entendida no sentido literal e figurado, na medida em que abarca dupla representação, uma de sentido denotativo, em se tratando de uma época de pandemias mundiais, como a gripe de 1918, e outro figurativo, entendido como padecimento social, gerado pela instabilidade econômica e falta de perspectiva de melhoria de vida. Apesar dos problemas, das enfermidades, os imigrantes seguiam mantendo a promessa pactuada quando partiram da Galícia para o Brasil: de trabalharem, ganharem dinheiro para sustentar a casa paterna e, um dia, se possível, retornarem.

A expressão "dos letras mal escritas" para se referir à carta, metonimicamente formada na relação dos letras/cartas (a parte pelo todo), era uma fórmula recorrente nas cartas pessoais, variante de "estas mal traçadas linhas", um recurso estilístico, que devolve a quem escreve a tarefa de não julgar o que está sendo escrito, do ponto de vista da forma e do conteúdo. É um caso de antecipação, com o intuito de resguardar o eu escrevente de qualquer mal-entendido oriundo da recepção e das interferências que atuam no ato da leitura e que independem de quem escreve.

O primeiro parágrafo é marcado por expressões de polidez, esperança e humildade, importantes para o engate da conversa. Neste sentido, os clichês mostram-se funcionais, agrupando expressões cristalizadas, usadas quando não cabe ao escrevente inovar, mas dizer o esperado, recorrendo a fórmulas repetidas, consolidadas, aceitas pelos interlocutores. Neste momento e lugar da carta, não é oportuno narrar as novidades, colocar em risco o contato, e o clichê cumpre uma função significativa, conversacional, na preparação do interlocutor para a recepção das notícias. A exposição gradativa traduz, portanto, uma estratégia discursiva na comunicação, na medida em que afeta o comportamento do destinatário, atuando na sua maneira de acolher as notícias e aderir ao que é exposto pelo remetente. 
Na sequência, no corpo da carta, o escrevente inicia, mais uma vez, com o vocativo, padre, não apenas para marcar o lugar identitário de ambos, mas para manter o contato, como se estivessem em uma conversa presencial. É um recurso característico das conversações, chamando a atenção para um tema ou para a mudança de assunto, como neste caso da carta, marcado estilisticamente pela mudança de parágrafo. Neste início, o filho acusa o recebimento da carta do pai e diz que está sabendo de tudo que se passa com a sua família na Galícia. A carta mostra que o escrevente evitava tratar de notícias ruins com o pai: "pois es berdad porque sinon causaba un choque para usted y la família"14. O sujeito escrevente não tinha a intenção de informar tudo que se passava com os imigrados, mostrando que a sua escrita era seletiva, opaca, produto das condições de produção, do contexto. Apesar de dizer que preferia evitar assuntos dolorosos, o escrevente, diante do conhecimento do pai sobre o fato, confirma os acidentes. Ao dizer que omitiu do pai um assunto, o escrevente tenta recuperar a confiança junto ao patriarca, por meio do gesto da confissão, amplamente valorizado na cultura ocidental, e que, como tal, exige, em contrapartida, um perdão. $\mathrm{O}$ eu escrevente trata de se antecipar, colocando-se em posição de humildade, ao tempo que justifica a sua atitude baseando-se no discurso da proteção, da preservação da saúde do pai. Do ponto de vista discursivo, este gesto de mão dupla - confessar/perdoar - restabelece o pacto de confiança que consiste em não esconder nada de si para o outro. Ao fazer uso do filtro, da seleção, revela-se a manipulação e, então, a relação de confiança é fissurada. Ao dizer que "nunca pensei que se escapase" (grifo meu), o remetente reforça a ideia de que a morte anunciada deveria ser poupada à família, ao tempo que demonstra que não houve intencionalidade em ocultar a notícia, desfazendo qualquer rasura à sua imagem, em um claro exemplo de construção do eu. O modalizador temporal de valor negativo nunca sugere certeza, convicção,

\footnotetext{
${ }^{14}$ Do ponto de vista lexical, vale a pena destacar a mescla do idioma galego com o castelhano.
} 
justificando assim a conduta do escrevente ao omitir a notícia. Cabe aqui citar Barcia, ao definir modalizador discursivo, conceito fundamental para entendermos a importância do corpo lexical das cartas para a construção do eu:

Por modalización discursiva entenderemos el modo de manifestación de la toma de postura del emisor frente al texto (...) y al destinatario a través de distintas marcas lingüísticas presentes en los textos que revelan, justamente, dicha posición. (BARCIA, 2012, p. 149)

Deste modo, o uso do lexema padre tem função redacional, ao servir para marcar o parágrafo, mas, também, ao compor o quadro lexical do escrevente, repetidamente, invocar a atenção do pai, fazendo-o lembrar do laço que os une.

Após fazer referência aos acidentes, já mencionados, o sujeito escrevente retoma uma fala usada pelo pai: "me dice que nosostros todos estamos enfermos". A sequência "me dice que", que caracteriza o discurso indiretoverbo dicendi acrescido do pronome relativo que- nos dá a entender que se trata de uma retomada da voz do pai, para reintroduzir um novo assunto na carta.

Na sequência, o escrevente trata da situação da sua tia que queria se casar, mas o pretendente não era bem visto porque "es um homen que non tem cheito de vida", o que significava dizer que não tinha ambições, não correspondendo, deste modo, ao perfil esperado de um marido, sobretudo quando o compara com a sua tia: "es uma muger que se balle dela costura". A combinação léxica "no tem cheito de vida" apresenta uma expressão coloquial que significa vida desordenada, sem sentido, sem rumo.

Os casamentos sempre foram na Galicia rural um arranjo entre famílias, com vistas a se desenvolverem economicamente, o que tornava as alianças majoritariamente endogâmicas, territorialmente e etnicamente. Portanto, uma das características a se observar para a realização do consórcio era o patrimônio material e imaterial das famílias, para preservá-lo e ampliá-lo. 
O sujeito escrevente se mostra determinado a impedir o enlace, mas, ao mesmo tempo, se apresenta cuidadoso. Informa ao pai que a tia resistiu e o enfrentou dizendo que não se casaria com outro, ou seja, que não estava disposta a se casar por imposição paterna ou por interesses da família. Do ponto de vista das relações de gênero, o discurso indireto-traço discursivo e narratológico que enuncia a tomada de fala do outro- sugere a presença da voz da mulher, mas ela não existe no texto como autorrepresentação, mas como representada. Nós não temos a voz dela, mas a do escrevente, que tenta criar uma imagem para o pai de uma mulher de natureza difícil, ao tempo que se mostra compreensivo, com vistas a influenciar o seu interlocutor-a quem o escrevente invoca na condição de conselheiro. É oportuno destacar que em se tratando das relações de gênero, portanto dos papeis sociais alicerçados nas diferenças sexuais, observamos neste trecho que há um deslizamento semântico em relação ao discurso hegemônico sobre os papeis sociais da mulher urbana: de esposa e mãe exclusivamente, para o de esposa-mãe-provedora-auxiliar. Esta realidade mostra o importante papel das mulheres galegas no processo de adaptação dos imigrantes no novo país.

E, por fim, o escrevente trata da colheita do milho, referindo-se à sua tia Casemira. Por estar pouco legível, apenas cito a passagem para destacar os assuntos e como são gradativamente expostos: o primeiro assunto visa restabelecer a confiança, já o segundo e o terceiro costuram os laços da credibilidade.

Retomando os aspectos textuais da carta, esta segue o modelo de desfecho, desejando lembranças, enviando abraços, gestos que denotam afeto e respeito:

padre para esta non lhe consomas solo que Receba lenbranças de sua futura filha concepçion y su madre y de meus tios y tia y primos y 
Ermanos y da miña parte

Receba um apertado abraço

ja que non podo dalo enpersona

su higo que mucho lequere

y deseia berlo.

Da mesma maneira que o introito, a conclusão também recorre ao clichê, com fórmulas repetitivas, preparando o interlocutor para a despedida. Observo no enunciado "padre para esta no lhe consomas" uma construção discursiva que desloca para o destinatário o motivo do desfecho, dando a entender que o encerramento da carta não é por vontade do escrevente, mas em atenção ao seu interlocutor, suavizando, assim, o rompimento momentâneo. Na sequência, ao se referir a alguns familiares, o escrevente mostra a rede formada no país de acolhida e sugere que, mesmo longe da casa de origem, estavam unidos à Galícia.

\section{SEGUNDA CARTA}

A segunda carta de Cándido Leiro Duran foi escrita em papel timbrado do armazém que tinha como sócios os Irmãos Leiro, o que sugere organização nos negócios e estabilidade profissional. Ademais, ao enviar uma carta manuscrita em papel timbrado do negócio empreendido, mostra à casa de origem, que os imigrantes estavam bem e que a viagem fora exitosa, dando mais tranquilidade, esperança e prestígio para os que viviam na Galícia. Um filho que retornasse para a Galícia sem alcançar melhoria econômica, era visto como um fracassado e esta condição expunha não apenas o retornado, mas todo o grupo familiar. Deste modo, dar boas notícias aos familiares era também uma maneira de proteger os seus membros da maledicência.

Do ponto de vista do propósito, esta carta de Cándido traz uma preocupação do pai com os matrimônios realizados na Bahia: 
Pois meu bom pai sobre oqueme dí sobre Algumas Coisas, antes así doque ao Contrário, pois tambem já Cuantos casamentos vai ter por ahí, pois atodos desejo saude e felizidade [e] ${ }^{15}$ corajem para enfrentar as dificuldades na estrada da vida.

A resistência aos casamentos com brasileiras aparece nos estudos realizados por Celia Braga, quando destaca a oposição dos galegos de aceitarem os casamentos dos imigrados com não-galegos (BRAGA, 1995, p. 115,). O objetivo dos matrimônios era fazer com que as uniões das famílias e a cultura galega fossem preservadas e protegidas de costumes que fossem diferentes e conflitantes com os dos galegos, ainda que, a meu ver, seja possível perceber pontos de convergências entre as culturas galega e a afro-brasileira ${ }^{16}$, por exemplo. No entanto, mesmo se casando com galegos ou galegas, a adaptação ao novo país implicava no contato com a cultura local, e os galegos imigrados e descendentes acabavam adotando hábitos e costumes de outros grupos socioculturais, mas sem perder, com isso, a sua ligação com a Galícia e o seu patrimônio cultural.

No excerto citado, o sujeito escrevente sugere recuperar, mais uma vez, um assunto da carta do pai, por meio do discurso indireto "sobre o queme di", o que nos leva a inferir que os pais estavam muito preocupados com os casamentos em Salvador. No entanto, a resposta firme do escrevente tem efeito sentenciador, ao destacar a quantidade de casamentos feitos na Galícia. O uso da sequência lexical "Algumas Coisas" deixa uma lacuna no plano semântico. O

\footnotetext{
${ }^{15}$ Ilegível.

${ }_{16}$ Alguns traços culturais dos galegos se aproximam muito dos rituais afro-brasileiros. Tanto os galegos quanto os africanos eram provenientes do rural. A relação que os dois grupos tinham (e têm) com a natureza, por exemplo, é muito similar, justamente porque viviam, no país de origem, da agricultura, da pecuária (ganaderia). São grupos, por exemplo, que conhecem as folhas e as usam na culinária, na medicina popular e nos rituais místicos.
} 
que seriam exatamente essas coisas? A que se referiam? Este interdito marcado pelo silêncio sugere que o assunto já era conhecido de ambos e que deveria ficar apenas entre eles, sendo desnecessário ser reescrito. Na sequência, outra lacuna presente no enunciado "antes así doque ao Contrário". Está claro que "así" diz respeito ao casamento, por referência catafórica, e "ao Contrário", por comparação e oposicionalidade - marcada pela partícula comparativa do que - ao antagônico: estar solteiro ou amasiado. Ao dizer ao pai que é melhor estarem casados, do que o contrário, resta ao leitor preencher este último hiato com solteiro ou amigado, o contrário de estar casado. O escrevente recorre ao ritual (o matrimônio), fundamental para os galegos, em detrimento do contexto, para tentar tranquilizar o pai e familiares.

A carta conta ainda com um pedido feito ao pai para que mandasse notícias de sua cunhada, a quem lhe havia escrito e não lhe contestara e, também, com um informe sobre o destino de outros galegos que chegavam a Salvador, mas, que, por alguma razão, não ficavam com os parentes e faziam o seu próprio caminho. Este destaque, escrito no post scriptum, nos mostra que os galegos já estabelecidos acolhiam os recém-chegados, mas estes deveriam se comportar de acordo com as regras combinadas na preemigração. No entanto, a distância entre os dois lugares e a liberdade que tinham no país de acolhida favoreciam as rupturas dos contratos e os imigrantes recém-chegados trilhavam o seu próprio caminho, às vezes com sucesso: "tamben-me dira alguma de cisa17 de minha tia Casemira e Meus primos pois Judalecio trabalhou com nos uma semana e dipoes arribou Sem notícias e sem prestar satisfação.18" Neste trecho, podemos perceber não apenas um aspecto do ritual imigratório, de acolher novos imigrantes e iniciá-los em uma profissão, mas o escrevente mostra-se preocupado com o destino de um deles e, ao mesmo tempo, se exime de

\footnotetext{
${ }^{17}$ Coisa.

18 Optei por omitir os nomes das pessoas por uma questão de privacidade.
} 
qualquer responsabilidade, no caso de o neófito romper com o contrato. $\mathrm{O}$ escrevente mostra-se cumpridor de sua missão, ao acolher os recém-chegados e oferecer-lhes trabalho, mas caso não concordassem em ficar, era imediatamente comunicado à família na Galícia. O fato de ter sido escrito após o encerramento da carta e na margem do papel, sugere que era um assunto que não deveria esperar o próximo envio, tinha logo que chegar ao conhecimento dos familiares na Galícia. A forma de ordenar os lexemas para narrar o episódio evita o julgamento direto, explícito. De um lado um grupo empregador que acolhe, oferece trabalho, do outro o empregado que abandona, não avisa e não justifica. A imagem do imigrante ingrato se forma, sem que o escrevente precise dizer diretamente ao seu interlocutor. A gradação "Sem notícias e sem prestar satisfação" forma uma imagem negativa do imigrado acolhido, marcado pela dupla presença no enunciado da preposição sem, que significa ausência ou exceção.

O pai era o centro receptor e emissor das notícias, do mesmo modo que o escrevente e os seus irmãos também eram em seus círculos familiares no Brasil. Os votos de saúde, felicidade e coragem são três anseios compreensíveis em tempos de pandemias, fome, profunda tristeza, desesperança e medo, pois embora não esteja explícito na carta do escrevente, as condições dos imigrados nos navios eram tão insalubres que dificilmente não contraiam enfermidades ou apresentavam debilidades físicas decorrentes da desnutrição e da tristeza. (MAGARIÑOS, 1999, p. 62).

O outro assunto da carta refere-se ao silêncio da cunhada do escrevente, e já que mencionei as mulheres galegas anteriormente, do ponto de vista das relações de gênero, é oportuno dizer que o silêncio da cunhada pode significar desvio a um tema delicado, quiçá uma inconformidade. Ademais o fato de o sujeito escrevente ter uma expectativa, e pelo modo como a apresenta, "não sei se não a recebeu ou senão quis contestar", pode ser explicado pela 
"modalización epistémica de incerteza" (BARCÍA, 2012), marcada pela partícula se e pela conjunção ou, sendo que o enunciado "não sei se não a recebeu" isenta a pessoa de qualquer responsabilidade, afinal a carta pode ter sido extraviada, mas o enunciado a seguir, já expõe um ato intencional, marcada pelo verbo querer em "não quis contestar". O silêncio não significa ausência de sentido, na medida em que a significação não ocorre apenas no plano do dito, falado ou escrito, o interdito é materializado na escrita por meio de desvio de assunto, enunciados superficiais e lacunares, marca gráfica de reticências, retomada de assunto anterior, enfim, recursos textuais e discursivos. O fato de o escrevente externar o possível ato voluntário da cunhada, em não querer falar com ele, implicitamente sugere que há um mal-estar entre ambos, e enseja, sub-repticiamente, que o pai intervenha.

O fato é que não dispomos das cartas do pai do escrevente, apenas as cartas dos filhos, nem mesmo as cartas das mulheres existem ou foram disponibilizadas, exceto quatro de Judith (Edith) e uma de Aurora. Esta lacuna nos chama a atenção, pois pelas palavras do escrevente, é possível constatar que ele se correspondia com algumas delas, mas essas cartas não existem ou não foram apresentadas para esta investigação. O importante é sinalizar que ao colocar uma alternativa - ou a carta foi desviada ou rejeitada-o remetente expressa o seu incômodo diante do silêncio da cunhada, mas sem deixar transparecer qualquer insinuação preconcebida, optando, assim, pela elegância da dúvida. Este aspecto é fundamental do ponto de vista do discurso porque mostra como as cartas foram determinantes para que as relações não sofressem desgastes e as redes simbólicas fossem preservadas. 
O assunto principal desta carta é o anúncio do casamento do escrevente:

\author{
Meus paes ${ }^{20}$ \\ esta não é uma Resposta de alguma carta \\ vosa, porén sím a simples novidade \\ que nos casamos no dia 24 do \\ corrente, asi como os senhores \\ já devem ter em voso poder uma \\ carta que euvos escrevi atempo \\ esplicando-vos o dia que julgo estar- \\ des sientes,
}

O uso do modalizador epistêmico sim tem efeito de convicção, já que "se referirá al nivel de adhesión del redactor a la verdad de lo escrito." (BARCIA, 2012, p.149). Neste caso, a ocasião pede um modalizador assertivo, pois o casamento, por ser um ritual de grande importância para os galegos imigrantes, era sinal de preocupação por parte da casa matriz, exigindo do escrevente segurança no que irá comunicar. Trata-se de uma carta-apresentação:

Pois meu pae

quer dicer que contades mais com estes novos parçeiros i nora,

Asi Como tambem meus yrmãos

Contam com mais uma cunhada que saber-se-a portar-se no comprimento do seu dever, Asi como eu tambem ja tenho maior nú= maro de parentes porparte da minha mulher (...)

O escrevente apresenta a esposa ao pai como uma parceira na construção de uma família e, por extensão, na preservação dos valores galegos já que

\footnotetext{
${ }^{19}$ Carta escrita em 27 de novembro de 1928

${ }^{20}$ Palavra acentuada na letra " $\mathrm{e}$ ", provavelmente um "til", já que o mesmo sinal aparece na palavra "não".
} 
"saber-se-a portar-se no cumprimento do seu dever". Este enunciado, em forma de um clichê, produz sentidos que se entrelaçam intertextualmente e interdiscursivamente: visa se fazer entendido e aceito, na medida em que usa um enunciado já sedimentado na cultura, e que, por esta razão, ajuda a consolidar uma expectativa de gênero em relação a Judith (Edith)21; objetiva ainda criar uma imagem sobre o caráter ilibado da esposa, e sobre a escolha acertada do marido, criteriosa e em confluência com os interesses da família, e, por fim, tranquilizar os familiares na Galícia, sabendo-se que o casamento ocorreu dentro dos moldes galegos. Considerando que os matrimônios são entendidos como um empreendimento, um consórcio, havia uma forte pressão em relação aos casamentos que ocorriam em terras brasileiras, como havia mencionado antes. Ser uma parceira que sabe portar-se reúne duas representações: a de uma mulher trabalhadora e a de esposa e mãe. É oportuno destacar o rito, como um novo membro era incorporado à família-envolvendoo e situando-o em relação aos outros - a fim de que o recém-chegado se sentisse pertencente àquele grupo e toda a família o respeitasse como se fosse do próprio sangue. O uso dos lexemas que indicam o grau ou relação de parentesco demonstra como os rituais de inclusão dos membros se formavam, nesta carta em específico, o escrevente apresenta a esposa como "nora" e "cunhada", referências lexicais organizadoras das relações familiares.

\section{CONSIDERAÇÕES FINAIS}

Esta investigação se propõe a contribuir com os estudos sobre a imigração galega na Bahia e, por conseguinte, no Brasil, a partir de documentos do acervo pessoal da família Leiro, de Pazos de Borbén, Moscoso. Este corpus formado por 44 cartas manuscritas, trazido aqui na versão digitada, é parte da

\footnotetext{
${ }^{21}$ Judith Iglesias Leiro era chamada de Edith. Nós, netos, a chamávamos de vó Edith.
} 
história dos galegos e dos seus descendentes; forma um conjunto de escritos importantes para os estudos discursivos dos egodocumentos, da egosespecularidade e da ancestralidade discursiva. Faz-nos buscar, nos arquivos memorialísticos, a substância sígnica, ou seja, a palavra, por meio das narrativas orais, dos manuscritos, do percurso vivido e narrado de quem nos antecedeu e que nos faz pertencer a uma história que, para os galego-descendentes não começa onde se nasce, neste caso em terras brasileiras, mas, muito antes disso, quando os fatos históricos e as condições geradas na Galícia impuseram uma rota que se não era nova, do ponto de vista da experiência ibérica, era nas condições em que foi feita: uma travessia do atlântico da qual nenhum galego e descendente de galegos pode escapar ou se esquecer. A nossa missão intelectual é dar sentido a essa existência e daqueles que virão, rememorando o trajeto e produzindo novas existências narrativas.

\section{REFERENNCIAS}

BAKHTIN, Mikhail. Estética da Criação Verbal. Organização, Tradução, Posfácio e Notas de Paulo Bezerra; Notas da edição russa: Seguei Botcharov. São Paulo: Editora 34, 2016.

BACELAR, Jeferson. Galegos no Paraíso Racial. Salvador: Ianamá; CAO; CED, 1994.

BARCIA, Susana Rodríguez. El análisis ideológico del discurso lexicográfico: una propuesta metodológica aplicada a diccionarios monolingües del español. Verba, Compostela, v. 39, p. 135-159, 2012. Disponível em:

[https://revistas.usc.gal/index.php/verba/article/view/872]. Acesso em: 12 mar. 2021.

BRAGA, Celia Maria Leal. Memórias de Imigrantes Galegos. Salvador: Centro editorial e didático da UFBA, 1995.

FOWLER, Roger. Sobre a Linguística Crítica. Linguagem em (Dis)curso, Tubarão, v. 4, n. esp, p. 207-222, 2004. Disponível em:

[http://www.portaldeperiodicos.unisul.br/index.php/Linguagem_Discurso/article/view /296/310]. Acesso em: 20 jan. 2021.

GARCÍA, Félix López. De la entrada de la voz autobiografía en España y su aplicación al ámbito de la literatura (1854-1898). Hesperia: Anuario de filología hispánica, Vigo, n. 12, fasc. 2, p. 5-27, 2009.

Disponível em: [https://dialnet.unirioja.es/servlet/articulo?codigo=3149348]. Acesso em: 10 mar. 2021. 
GROßE, Sybille. Cartas e correspondência ordinária como ego-documentos na análise linguística. Linguíftica, Rio de Janeiro, v. 11, n. 2, p. 22-41, 2015. Disponível em: [https://revistas.ufrj.br/index.php/rl/article/view/4499/3270]. Acesso em: 12 mar. 2021.

LEIRO, Lúcia. Ancestralidade discursiva na literatura e nos filmes de animação infantil. Aulas na graduação de Prática de Leitura e de Produção de Texto na Universidade do Estado da Bahia, mar.-jul., 2021.

MAGARIÑOS, Alfonso. A Emigración. Santiago de Compostela: Laioviento, 1999.

VÁZQUEZ, Raúl Soutelo. Entre Ourense e América: a emigración nos proxectos de vida de diferentes tipos de famílias na Galicia rural (1880-1960). Ourense: Imprenta Halbagraf; Deputación de Ourense, 2017.

Nota do editor:

Artigo submetido para avaliação em: 28 de fevereiro de 2021.

Aprovado em sistema duplo cego em: 29 de junho de 2021. 